\title{
STUDENTS' VOICES ON ONLINE ENGLISH LEARNING
}

\author{
Akhmad Hairul Umam ${ }^{\text {a*) }}$ \\ a) Tanri Abeng University,Jakarta, Indonesia \\ ${ }^{*}$ e-mail korespondensi: ahmad.umam@tau.ac.id
}

\section{Riwayat Artikel \\ diterima 05 Juni 2021 \\ direvisi 29 Juni 2021 \\ disetujui 28 Juli 2021}

\begin{abstract}
The research study investigated the students' voices on online English learning during the Covid-19 pandemic. This study was taken in quantitative and qualitative approach using the questionnaire and interview in which the data were taken through an online with descriptive analysis. The research involved 46 participants who learned online English at higher education in Jakarta. Based on the result data, indicated that respondents who have been learning online English for one semester accepted moderately. Moreover, a few of them argued that online English learning during the Covid-19 as the best alternative to mitigate the spread of viruses in Education cluster. Participants showed big concern with health problem and made it as priority for their life decision in emergency situation of Covid-19 pandemic. Although the implementation of online English learning still has challenges and difficulties for students, they have optimism and slowly accustomed to use technology in language learning and becoming autonomous learning.
\end{abstract}

Keywords: Online English learning; student's voices; digital learning platform.

\section{SUARA MAHASISWA TERHADAP PEMBELAJARAN BAHASA INGGRIS ONLINE}

\begin{abstract}
Abstrak. Penelitian ini menyelidiki suara mahasiswa terkait pembelajaran bahasa Inggris daring selama pandemi Covid-19. Penelitian ini dilakukan melalui pendekatan kuantitatif dan kualitatif dengan menggunakan kuesioner dan wawancara dimana pengambilan data dilakukan secara daring dengan analisis deskriptif. Penelitian ini melibatkan 46 peserta yang belajar bahasa Inggris secara daring di perguruan tinggi di Jakarta Selatan. Berdasarkan data hasil penelitian, menunjukkan bahwa responden menilai model pembelajaran bahasa Inggris daring di masa pandemi Covid-19 ini diterima dengan cukup baik. Selain itu, terdapat beberapa opini yang menyatakan pembelajaran bahasa Inggris daring ini sebagai alternatif terbaik ditengah melawan penyebaran virus di klaster Pendidikan. Mahasiswa menunjukkan kepedulian yang besar terhadap masalah kesehatan dan menjadikannya sebagai prioritas dalam pengambilan keputusan hidup mereka di tengah situasi darurat pandemi Covid-19. Meskipun pelaksanaan pembelajaran bahasa Inggris daring dinilai masih memiliki tantangan dan kesulitan bagi mahasiswa, mereka memiliki optimisme dan perlahan-lahan terbiasa menggunakan teknologi dalam pembelajaran bahasa dan menjadi pembelajar yang mandiri.
\end{abstract}

Kata Kunci: Pembelajaran daring; suara mahasiswa; platform pembelajaran digital

\section{INTRODUCTION}

For the last two years online learning has been the most dominant learning system in Indonesia. Lately the use of technology and internet in education plays important role to make the teaching learning activities continually running, more interesting and flexible. No wonder if the online learning gains popularity in the mid of Covid-19 pandemic. However, the implementation of online learning has brought many changes and difficulties which are experienced both by teachers and students. The common challenges are found in the learning process, learning activities, and various ability to deal with online learning (Febriani et.al., 2020). As found in (Dhawan, 2020), although many digital learning platforms are available for online learning, students are still struggling especially with technical issues related to boot errors, installation issues, login issues, audio and video issues. Sometimes they fell online learning to be boring, unengaging, and the internet content is too theoretical and does not allow students to practice and learn effectively.

With regard to the problems in online learning above, there are possible solution that can be made by teachers for example, make a pre-recorded video, check the content, and make a plan B the teaching. In addition to that, online learning can be made more interesting, interactive and dynamic. Shifting the learning system from conventional to online learning during the pandemic is not easy especially if the students come from the diverse background of economy, facility, and place where they stay. According to Keeton, effective online study guides facilitate students feedback, encourage students to ask questions, and broaden students' horizons on course content. The challenges for teachers is not only finding and using the digital learning platform for delivering their teaching material but also engaging students to be proactive in their teaching (Keeton, 2004).

The present of online learning in Covid-19 pandemic not only creates problems but also advantages for instance easy interaction and delivering teaching materials. Through online learning, the interaction between teachers and students or among students can be made flexible. Students can share information or opinions on various issues relating to lessons and other needs for their personal-development. Awhile teachers anytime and anyplace can put teaching materials that 
can be downloaded by students and assign assignments to students and collect them through digital learning platforms being used by the teachers. Moreover, interaction can also be made in synchronous and asynchronous learning between students and teachers or among students through online forum.

It goes without saying Covid-19 pandemic indirectly has given significant contribution in the development technology and forcing a learning style of students from offline to online learning. As a result, the new way of leaning automatically could impact students' learning behavior and acceptance as well. The United Nations has recently reported that the Covid-19 pandemic has caused the biggest disruption to the education systems in history, affecting nearly 1.6 billion students in more than 190 countries and continents (United Nations, 2020). Globally, over 1.2 billion students between elementary up to university level are off school (Ab Rahman et.al., 2019). One of the main challenges found in online learning is the "disconnect between the way teachers were taught to teach", and how the course content must be delivered in an effective online classroom. Further Anderson et al. (2011) explained that the feedback they received from students seldom helped them in adjusting their teaching as they would in a face-to-face class (Anderson at al., 2011).

There are a number of digital learning platform can be used in conducting online learning for instance google classroom, zoom, skype, and other learning management systems. Of course, the appropriate learning tools must be taken properly based on the preference and ability in accessing technology like students' condition and other support systems. Here the digital learning platform should be understood as a tool to help both teachers and students manage the learning system for the implementation of the teaching and learning process. For example using Google Classroom in online learning can support teachers to manage the classroom activity effectively and efficiently (Azhar \& Iqbal, 2018).

The term of online learning has a very broad definition. In general understanding, online learning can be perceived as virtual learning mediated by technology. For the purpose of this research study, the concept of online learning refers to a type of teaching and learning situation in which (1) the student is at a distance from the teacher, (2) the student is using some kind of technology to access the teaching material, (3) the student is using technology to interact with the teacher and with other students and (4) some form of support is provided to learners. Most teaching and learning take place in the same online environment as teaching and learning in any other formal educational context (T. Anderson, 2011).

Observing the new model of learning from offline to online classroom learning during the Covid-19 in Indonesia, it is interesting to investigate the students' voices regarding to their experiences to have an online English learning with case study at higher education. This is consistent with a study by (Mailizar et al. 2020), which reported that students' voice on the online English learning is essential in measuring the effectiveness of teaching learning activities. Based on the facts above, this study attempts to investigate students voices how they feel, think, and hope for the implementation of online English learning during the Covid-19 pandemic. Therefore, the specification of research questions is directed to answer two questions 1 . What is the voices of students toward online English learning? 2. What are the challenges in online English learning?

\section{RESEARCH METHOD}

The aim of this study was to investigate students' voices for online English learning during the Covid-19 pandemic. The distributed questionnaires and interviews were conducted during the online class activities. The obtained data were identified, analysed and described descriptively. It is in line with Creswell who states that mixed methods utilize the strength of both qualitative and quantitative research (Creswell, 2009). The questionnaire items were adapted from (Cirocki et al., 2019). The participants were asked to rate each statement or questions by their level of agreement (Agree, Disagree, Neutral). Though the questionnaires of research study are already established, there are possibilities that the questionnaires do not address and resolve unpredicted issues that emerge from the students' experience in online English learning. In addition to that, I invited a few students randomly to get an online interview. It's taken to let them to express their thoughts due to the restricted questions or statement of the questionnaire.

\section{RESULTS AND DISCUSSION}

As stated above the aim of this study is to investigate the students' voices toward the online English. Therefore, the interpretation of the results of this study in accordance with the design of the research study which are divided into two sections. The first section is students' voices that consist of reasons what they like and don't like on online English learning. The second section is to explore about challenges of online English learning. The percentage distribution for students' voices toward online English learning can be seen in Table 1 and 2.

Total participants who contributed for this study were 46 students. They took English course during the pandemic for one semester. Looking to the gender, $65,2 \%$ females and $34.8 \%$ females. Most of the participants are between 20-22 years old. Awhile devices used by students to access the online English learning, 70\% of the participants used laptops and $30 \%$ used smart phones. Apart of teaching materials provided by their teacher, the students also used other resources for developing their English skill like YouTube $40 \%$, social media $30 \%$, Google $20 \%$, other websites provide English materials $10 \%$.

\section{A. Students'Voices}

This part presents and discusses the findings related to the research questions on students' voices cope with the experiences on online English training during the Covid-19 pandemic. The discussion is seen through the interpretation of the results shown in the Tables elaborated with the findings from the survey. As seen at table 1 indicated that the majority of students show positive acceptance toward the online 
English learning during the pandemic. Most of the items for the questionnaires received positive responses. It means that students accepted the online English learning moderately as best alternative learning during the pandemic due to flexibility of learning that allow them to study from their home any time and any places. If we look through in detail each item of the questionnaire has high percentage of agreement from the participants range from $50 \%$ to $85 \%$. This can be interpreted that majority of the participants agreed to the given statement and only a few them chose the option of disagreement and being neutral especially with statement of number 5,6 , and 7 in with percentage range from $21,7 \%$ up to $43,5 \%$ which is less than $50 \%$ of the total respondents. Looking back to the high percentage given by the participants at Table 1 , informed the readers that online English learning reasonably is enjoyable compared to offline learning which is expected to mitigate the migration of Covid-19 in the education cluster. It is also perceived that the degree of the students' voices of agreement in this section is statistically significant. On this part, students have high acceptance to accept and participate the learning English online in the mid of Covid-19 pandemic.

Table 1 Students' Voices on Online English Learning

\begin{tabular}{|c|c|c|c|c|}
\hline No & Questionnaire & Agree & Disagree & Neutral \\
\hline 1 & $\begin{array}{l}\text { I enjoy learning } \\
\text { English } \\
\text { because I can study in } \\
\text { comfort. }\end{array}$ & $\begin{array}{c}58,7 \\
\%\end{array}$ & $10,9 \%$ & $30,4 \%$ \\
\hline 2 & $\begin{array}{l}\text { I love learning } \\
\text { English online } \\
\text { because it is flexible. }\end{array}$ & $\begin{array}{c}69,6 \\
\%\end{array}$ & $2,2 \%$ & $28,3 \%$ \\
\hline 3 & $\begin{array}{l}\text { I enjoy learning } \\
\text { English online } \\
\text { because I can study } \\
\text { at home. }\end{array}$ & $\begin{array}{c}80,4 \\
\%\end{array}$ & $6,5 \%$ & $13 \%$ \\
\hline 4 & $\begin{array}{l}\text { I enjoy learning } \\
\text { English online } \\
\text { because I can study } \\
\text { on my own. }\end{array}$ & $\begin{array}{c}71,7 \\
\%\end{array}$ & $6,5 \%$ & $21,7 \%$ \\
\hline 5 & $\begin{array}{l}\text { I prefer to learn } \\
\text { English online } \\
\text { because there is no } \\
\text { communication with } \\
\text { friends }\end{array}$ & $\begin{array}{c}34,8 \\
\%\end{array}$ & $39,1 \%$ & $26,1 \%$ \\
\hline 6 & $\begin{array}{l}\text { I love learning } \\
\text { English online } \\
\text { because there are not } \\
\text { many English } \\
\text { learning apps. }\end{array}$ & $\begin{array}{c}21,7 \\
\%\end{array}$ & $28,3 \%$ & $50 \%$ \\
\hline 7 & $\begin{array}{l}\text { I can learn English } \\
\text { well with online } \\
\text { learning. }\end{array}$ & $\begin{array}{c}43,5 \\
\%\end{array}$ & $4,3 \%$ & $52 \%$ \\
\hline 8 & $\begin{array}{l}\text { I enjoy learning } \\
\text { English online } \\
\text { because it works for } \\
\text { me. }\end{array}$ & $50 \%$ & $0 \%$ & $50 \%$ \\
\hline 9 & $\begin{array}{l}\text { I love learning } \\
\text { English online }\end{array}$ & $50 \%$ & $4,3 \%$ & $45,7 \%$ \\
\hline
\end{tabular}

because it helps me

to be more

independent and

responsible in my

studies.

10 I love learning

English online

because I need to

stay safe and healthy.

Slightly different, the Table 2 shows that participants have different views toward each item of the questionnaire. No single item received high percentage more than $50 \%$. Seemingly some responses from the students appeared to be in disagreement while some others seemed to be in different point of view between the position of agreement and neutral. This indicated that no majority participants who have similar responses in responding the questionnaires except the statement of online English learning make their English skill is getting slow or passive. For this statement, students have equal arguments between agreement and neutral. The detail percentage of this part and total items for the score of the questionnaire result can be seen at the following table.

Table 2 Students' Voices on Online English Learning

\begin{tabular}{|c|c|c|c|c|}
\hline No & Questionnaire & Agree & Disagree & Neutral \\
\hline 11 & I don't like learning & 17,4 & $39,1 \%$ & $43,5 \%$ \\
\hline & $\begin{array}{l}\text { English because I } \\
\text { can't study without } \\
\text { teacher's supervision. }\end{array}$ & $\%$ & & \\
\hline 12 & $\begin{array}{l}\text { I don't like studying } \\
\text { English because } \\
\text { there is no } \\
\text { interaction with the } \\
\text { teachers. }\end{array}$ & $\begin{array}{c}23,9 \\
\%\end{array}$ & $41,3 \%$ & $34,8 \%$ \\
\hline 13 & $\begin{array}{l}\text { I don't like learning } \\
\text { English online due to } \\
\text { poor internet } \\
\text { connection. }\end{array}$ & $\begin{array}{c}26,1 \\
\%\end{array}$ & $32,6 \%$ & $41,3 \%$ \\
\hline 14 & $\begin{array}{l}\text { I don't like learning } \\
\text { English online } \\
\text { because of the heavy } \\
\text { workload. }\end{array}$ & $\begin{array}{c}26,1 \\
\%\end{array}$ & $39,1 \%$ & $34,8 \%$ \\
\hline 15 & $\begin{array}{l}\text { I don't like online } \\
\text { English because the } \\
\text { teacher doesn't give } \\
\text { any explanation. }\end{array}$ & $\begin{array}{c}26,1 \\
\%\end{array}$ & $43,5 \%$ & $30,4 \%$ \\
\hline 16 & $\begin{array}{l}\text { I don't like learning } \\
\text { English online } \\
\text { because it is } \\
\text { monotonous and } \\
\text { boring. }\end{array}$ & $\begin{array}{c}30,4 \\
\%\end{array}$ & $45,7 \%$ & $23,9 \%$ \\
\hline 17 & $\begin{array}{l}\text { I don't like learning } \\
\text { English online } \\
\text { because teachers } \\
\text { provide too many } \\
\text { new apps that are } \\
\text { taking up space on }\end{array}$ & $\begin{array}{c}28,3 \\
\%\end{array}$ & $47,8 \%$ & $23,9 \%$ \\
\hline
\end{tabular}


my cell phone's

memory.

\begin{tabular}{|c|c|c|c|c|}
\hline 18 & $\begin{array}{l}\text { In my opinion, } \\
\text { learning English }\end{array}$ & $\begin{array}{c}17,4 \\
\%\end{array}$ & $43,5 \%$ & $39,1 \%$ \\
\hline 19 & $\begin{array}{l}\text { online is difficult. } \\
\text { I have faced many }\end{array}$ & $15 \%$ & $43,5 \%$ & $41,3 \%$ \\
\hline & $\begin{array}{l}\text { difficulties in the } \\
\text { process of learning }\end{array}$ & & & \\
\hline & English online. & & & \\
\hline 20 & I feel that when I & $50 \%$ & $0 \%$ & $50 \%$ \\
\hline & $\begin{array}{l}\text { study English online } \\
\text { my English level }\end{array}$ & & & \\
\hline & $\begin{array}{l}\text { becomes slower and } \\
\text { more passive. }\end{array}$ & & & \\
\hline
\end{tabular}

\section{B. The Challenges}

This part explores the opinion from students' perspective through interview. It was found that students have own perception toward the challenges and the opportunities of online English learning. According to the students the majority of the challenges on online learning are diverse ranging from internet connection, old devices, and teaching learning tend to be monotone. Although the online class is considered as the best choice in the mid of Covid-19 pandemic, the students argued that the online English learning should be conducted in more interactive such as by combining between synchronous and asynchronous learning. Here are some voices of students expressed by representative of students who took online English course.

"The online English learning was too long and monotonous. It could be made shorter so that the use of internet quota was less, more efficient and effective". Laila

"For me the implementation of online English learning during the Covid-19 pandemic is best one compared to offline learning. It forced me to learn how to be autonomous learner. I enjoyed a lot online English learning and developing my English skill individually through YouTube". Fitro

"During the Covid-19 pandemic I studied from home and away from the city. I used a smart phone for learning media. My internet network was unstable. It's difficult to fully participate on online English learning" Fika

From these excepts, it's clearly understood how students feel and face the challenges during their participation on online English learning. It should be noted that the way of teaching learning activities in offline and online is different. Teacher is supposed to deliver their teaching accordingly. In this case during the Covid-19 pandemic, the teachers can use a combination between the synchronous and asynchronous learning to minimize the internet use. In addition to that, the teachers should be aware with diversity of students' background in term of economic, places and the ability to get an internet access. Though the place of study is located in city, some of the students during the Covid-19 already back to their home due to the changing the policy of learning approach from offline to online. For those students who come from rural areas with poor internet connection, online learning will be very hard. Internet access is expensive in some part of
Indonesia, so some students prefer to conducts a balanced study session with less internet free consumption in the teaching and learning process.

Listening from the students' voices, at least 5 challenges found in online English learning based on percentage of responses such as internet connectivity as well limited internet quota, old and slow devices, difficulty to focus while learning online, lack of motivation due to the absence of face-to-face contacts, difficulty in understanding the content, and technical problems in using online learning method. What was conveyed by students is very much in line with the research conducted by (Bestiantono et al, 2020) who mentioned several factors, such as inadequate access, internet accessibility, lack of technology and the ability of students to participate in digital learning, and lack of proper interaction with educators, have become the main factors influencing learning. Moreover, according to Nambiar students claim online classes are poor quality. Things like disrupted class flow, difficulty clearing up doubts, lack of interest, technical glitches, and lack motivation to attend class are some of the important factors that reduce the effectiveness of online classes (Nambiar, 2020). Interestingly, during the interview students not only express their challenges but also opportunities or advantages of online English learning taken by students such as this new approach of learning encourages students to be more adaptive to technological developments. Students slowly get familiarization with the use of online tools and other digital learning platform that support them in their learning. Apart of that, students also have good awareness to be more independent and autonomous learner instead of depending a lot of their teachers

\section{CONCLUSION}

Looking back to the research result, it can be concluded that opinion of students about learning English online during the covid-19 is positive. They accepted the new approach of online English learning moderately. Though a few of students view the offline learning is ideal for them, they acknowledged and perceived that online English learning as best alternative approach during the pandemic. The common reason for students who are not prepared for online learning is due to internet connection and lack of technical skills for language learners to adjust with digital learning platform. Interestingly it's essential to highlight and acknowledge as well that the present approach of online learning has given the participants opportunities to learn English independently and motivated them as autonomous learners. As recommendation for further research, it is recommended to explore other voices from teachers' perspective and stake holder of education regarding their opinion and expectation towards online English during the pandemic. The limitation of this study is the small sample of respondents taken from one institution of higher education in Jakarta. It is hoped that this paper can be followed up with other research which is more comprehensive and engaging more respondents. 


\section{REFERENCES}

Ab Rahman, R., Ahmad, S., \& Hashim, U. R. (2019). A study on gamification for higher education students' engagement towards education 4.0. In Lecture Notes in Networks and Systems (Vol. 67). https://doi.org/10.1007/978-981-13-6031-2_5

Abid Azhar, K., \& Iqbal, N. (2018). Effectiveness of Google Classroom: Teachers' Perceptions. Prizren Social Science Journal, 2(2), 52-66.

Anderson, D., Imdieke, S., \& Standerfor, N. S. (2011). Feedback Please: Studying Self in the Online Classroom. International Journal of Instruction, 4(1), 3-16.

Anderson, T. (Ed.). (2011). The Theory and Practice of Online Learning. Edmonton: Athabasca University Press.

Bestiantono, D. S., Agustina, P. Z. R., \& Cheng, T.-H. (2020). How Students' Perspectives about Online Learning Amid the COVID-19 Pandemic? Studies in Learning and Teaching, 1(3), 133-139. https://doi.org/10.46627/silet.v1i3.46

Cirocki, A., Anam, S., \& Retnaningdyah, P. (2019). Readiness for autonomy in English language learning: The case of indonesian high school students. Iranian Journal of Language Teaching Research, 7(2), 1-18.

Creswell, J. W. (2009). Research desing: Qualitative, quantitative, and mixed methods approaches. Thousand Oaks, California: SAGE Publications.

Dhawan, S. (2020). Online Learning: A Panacea in the Time of COVID-19 Crisis. Journal of Educational Technology Systems, 49(1), 5-22. https://doi.org/10.1177/0047239520934018

Febriani, S. R., Widayanti, R., Amrullah, M. A., \& Mufidah, N. (2020). Arabic learning for elementary school during COVID-19 emergency in Indonesia. OKARA: Jurnal Bahasa Dan Sastra, 14(1), 67-80. https://doi.org/10.19105/ojbs.v14i1.3194

Keeton, M. T. (2004). Best Online Instructional Practices: Report of Phase I of an Ongoing Study I. Principles of Best Practice. Jaln, 8(2), 75-100. Retrieved from https://wcpss.pbworks.com/f/BP+Online.pdf

Mailizar, Almanthari, A., Maulina, S., \& Bruce, S. (2020). Secondary school mathematics teachers' views on elearning implementation barriers during the COVID19 pandemic: The case of Indonesia. Eurasia Journal of Mathematics, Science and Technology Education, 16(7). https://doi.org/10.29333/EJMSTE/8240

Nambiar, D. (2020). The impact of online learning during COVID-19: students' and teachers' perspective. The International Journal of Indian Psychology, 8(2), 783793. https://doi.org/10.25215/0802.094
United Nations. (2020). Policy Brief: Education during COVID-19 and beyond (August 2020) - World ReliefWeb. Report Uinited Nations, (August), 26. Retrieved from https://reliefweb.int/report/world/policy-briefeducation-during-covid-19-and-beyond-august-2020 